\title{
Early response of Pinus radiata plantations to weed control and fertilization on metamorphic soils of the Coastal Range, Maule Region, Chile
}

\author{
Respuesta temprana de Pinus radiata al control de malezas y la fertilización en suelos \\ metamórficos de la Cordillera de la Costa de la Región del Maule
}

\author{
Rafael Rubilar ${ }^{a *}$, Leandra Blevins ${ }^{b}$, Jorge Toroc ${ }^{c}$, Antonio Vitad, Fernando Muñoz \\ *Corresponding author: aUniversidad de Concepción, Facultad de Ciencias Forestales y Cooperativa de Nutrición Forestal, \\ Victoria 631, casilla 160C, Concepción, Chile, tel.: 56-41-2204980, fax: 56-41-2255164, rafaelrubilar@udec.cl \\ ${ }^{\mathbf{b}}$ Forest Nutrition Cooperative, North Carolina State University, Forestry Department, Raleigh, NC USA. \\ 'Calle Uno 394, Villuco, Concepción, Chile. \\ dUniversidad de Chile, Facultad de Ciencias Forestales, Santiago, Chile. \\ eUniversidad de Concepción, Facultad de Ciencias Forestales, Concepción, Chile.
}

\begin{abstract}
SUMMARY
Management of Pinus radiata plantations in Chile has been intensified in the last decades using site preparation, weed control and fertilization. The lack of information on site-specific responses imposes uncertainty about the biological and economic benefits of these techniques. Early projection of initial tree growth response to intensive culture is extremely important but difficult to estimate unless a clear understanding of limiting resources exists at each site. Based on the three-year development of a weed control and fertilization trial located on metamorphic soils of the Coastal Range of Chile we investigated the site specific limitations at these sites. Fertilization treatments included no fertilization (F0) and fertilized (F1) $(26 \mathrm{~g} \mathrm{~N}+16.7 \mathrm{~g} \mathrm{~K}+$ $2.5 \mathrm{~g}$ B per plant). Banded weed control treatments on woody vegetation included one (WC1) and two consecutive years (WC2) of release. After 12 months, seedling survival was significantly increased by weed control but not by fertilization. Three years after establishment, weed control increased survival by 13\%, and intensive silvicultural treatment gains were $56-103 \%$ for root collar diameter (RCD), 53-82\% for height (HT), 269-591\% for volume index $\left(\mathrm{V}=\mathrm{D}^{2} \mathrm{H}\right)$, and $35-77 \%$ for crown diameter $(\mathrm{CR})$. Lack of fertilization response suggested that water was the most limiting resource. Weed control responses represented almost one growing season gain in tree growth. No additional gains were obtained by weed control of woody vegetation during the second growing season. A linear relationship was found between $\log (\mathrm{CR})$ and $\log (\mathrm{V})$, suggesting a simplified method to estimate tree vigor at early stages of plantation development.
\end{abstract}

Key words: site specific silviculture, nutrients, water, growth efficiency, tree establishment.

RESUMEN

El manejo de las plantaciones de Pinus radiata en Chile se ha intensificado en las últimas décadas por medio de preparación de suelo, control de malezas y fertilización al establecimiento. Sin embargo, la falta de información respecto a las respuestas específicas al sitio impone incerteza acerca de los beneficios económicos y biológicos de las técnicas silviculturales aplicadas. La proyección del crecimiento inicial a los tratamientos silviculturales es crítica, pero difícil de estimar, a menos que se tenga una clara comprensión de los factores limitantes del sitio. Se investigó la respuesta de crecimiento y el uso potencial del diámetro de copa como un indicador temprano de vigor de la plantación a los tres años para la duración del control de malezas y la fertilización en un ensayo localizado en suelos metamórficos de la Cordillera de la Costa de la Región del Maule. Los tratamientos consideraron sin fertilización y fertilizado $(26 \mathrm{~g} \mathrm{~N}+16,7 \mathrm{~g} \mathrm{~K}+2,5 \mathrm{~g}$ B por planta). Los tratamientos de control de vegetación competidora consideraron uno y dos años consecutivos de control de malezas en bandas. Después de 12 meses la supervivencia fue mayor con el control de malezas pero no con la fertilización. La respuesta al control de malezas fue muy alta y se mantuvo hasta el tercer año. La falta de respuesta a la fertilización sugiere que el agua es el principal factor limitante para estos sitios. Tres años después del establecimiento el control de malezas aumentó la supervivencia en 13\%, y los tratamientos de mayor intensidad silvicultural produjeron ganancias de 56-103\% en diámetro de cuello, 53-82\% en altura, 269-591\% en índice de volumen y $35-77 \%$ en diámetro de copa. Estas respuestas correspondieron a una ganancia de una temporada de crecimiento. El control de malezas durante dos años consecutivos no produjo respuestas de crecimiento. La relación lineal obtenida entre diámetro de copa e índice de volumen sugiere un método simple para estimar vigor de la planta en etapas tempranas. Las distintas relaciones lineales para los tratamientos aplicados sugieren limitaciones hídricas en la eficiencia de crecimiento para tratamientos que incluyen control de malezas de aquellos que no lo presentan.

Palabras clave: silvicultura específica, nutrientes, agua, eficiencia de crecimiento, establecimiento de plantaciones. 


\section{INTRODUCTION}

Radiata pine (Pinus radiata D. Don) is the most important commercial forest species in Chile. There were approximately 1.4 million ha of radiata pine plantations in Chile in 2003 (INFOR 2004), and 61,560 ha were established in 2005 (INFOR 2006) at an estimated cost of US\$ 24.6 million. During the last 20 years, there has been a shift from extensive to intensive pine silviculture in Chile (Gerding 1991, Toro et al. 1998). Although new silvicultural techniques have increased plantation productivity, establishment costs have doubled over the last ten years (Valdebenito and Hormazábal 2000). Intensive management has been applied sometimes with uncertain biological and economic benefits. Intensive plantation management in Chile has relied on an empirical understanding of site limitations rather than the use of site-specific information (Geldres and Schlatter 2004, Turner et al. 2001, Toro 2004). Foreign and domestic experiences indicate that accurate soil and site information, an understanding of resource availability, and the use of ameliorative treatments such as site preparation, fertilization and weed control, are required to obtain full benefits of intensive silviculture (Kogan et al. 1992, Toro et al.1998, Turner et al. 2003, Albaugh et al. 2004, Allen et al. 2005, Mead 2005). Since establishing forest plantations require long-term investments, it is crucial to predict site-specific responses in order to make cost effective management decisions (Nambiar and Sands 1993, Richardson 1993, Mason 1994, Mason and Milne 1999, Allen et al. 2005, Mead 2005, South et al. 2006).

The effect of woody and herbaceous weed control on radiata pine has been extensively investigated, and on some sites, it may double forest productivity by mid-rotation (Balneaves and Henley 1992, Richardson 1993, Mason and Milne 1999). Several empirical and mechanistic approaches have been used to model the response to weed control (Richardson et al. 1999, Watt et al. 2003ab, South et al. 2006). Regardless of the modeling approach, appropriate prediction of weed control gains on plantation productivity is highly site specific and species dependent, and there is a need to identify the critical periods during which weed control will have the greatest effect on pine productivity (Radosevich and Ousteryoung 1987, Powers and Reynolds 1999, Richardson et al. 2006).

This study evaluates the 31 months response to weed control duration and fertilization at establishment of radiata pine growing on metamorphic soils of the Coastal Range of Chile. These sites have a widespread distribution on the western side of the Coastal Range, where intensive culture is being widely used to establish first and second rotation pine plantations. In addition, we investigated the site specific limitations and the potential use of individual tree crown diameter (CR), a surrogate for leaf area, as an early indicator of tree vigor.

\section{METHODS}

Site characteristics. The site is located on an undulating ridge top (slope $<20 \%$ ) on the western side of the Coastal Range, $10 \mathrm{~km}$ north of Constitución, Chile (Maule Region). Soils are well to moderately well-drained. The soils have loam to loamy clay superficial textures with a rapid increase of clay and coarse fragments (30-60\%) at depth (Forestal Celco S.A., Soil Mapping Program). Soils are Constitución series derived from metamorphic parent materials and extend over an area of 377,000 ha (CIREN 1999). Annual rainfall averages $708 \mathrm{~mm}$ distributed predominantly during winter (figure 1). Mean monthly temperatures range from 8.5 to $19^{\circ} \mathrm{C}$ (Santibáñez and Uribe 1993). The natural vegetation in the area is described as "bosque caducifolio maulino" association, which is composed mainly of hualo (Nothofagus glauca (Phil.) Krasser.), roble (Nothofagus obliqua (Mirb.) Oerst.), maquicillo (Azara petiolaris (D. Don.) Johnst.), maqui (Aristotelia chilensis (Mol.) Stuntz.), litre (Lithraea caustica Hook. et Arn.), zarzaparrilla (Ribes punctatum Ruiz et Pav.) and mayu (Sophora macrocarpa J. E. Sm.). Competing vegetation on the study site was predominantly roble (N. obliqua) and zarzamora (Rubus ulmifolius Schott).

Following a wildfire and timber salvage operation, the site was prepared in 1993 using a TTS-Delta Disk Trencher (TTS-Delta, Inc), resulting in raised beds 1.2 $\mathrm{m}$ wide and 25 to $30 \mathrm{~cm}$ high. Pre-planting broadcast weed control (hexazinone $2 \mathrm{~L} \mathrm{ha}^{-1}$ ) was applied after site preparation.

Experimental design and treatments. The site was planted in July 1994 using 1-0 bareroot seedlings from a single half-sib genetic family. Spacing of the new plantation was $4.0 \mathrm{~m}$ between beds and $2.5 \mathrm{~m}$ within beds. The seedlings were planted on the center of the bed with a spade.

In October 1994, the study was established as a randomized block split-plot design with three replicates. Main plots, $25 \mathrm{~m}$ wide and $50 \mathrm{~m}$ long received either no fertilization (F0) or fertilization (F1) treatments. Fertilized seedlings received $26 \mathrm{~g}$ of nitrogen, $16.7 \mathrm{~g}$ of potassium and $2.5 \mathrm{~g}$ of boron ( $45 \mathrm{~g}$ of urea, $45 \mathrm{~g}$ of potassium nitrate and 25 $\mathrm{g}$ of boronatrocalcite). According to soil analyses of the area, only nitrogen, potassium and boron were considered critical at the time of establishment (Forestal Celco S.A.). Fertilizer was applied in two slits $20 \mathrm{~cm}$ from the seedling, and approximately $20 \mathrm{~cm}$ deep. Split-plots, $25 \mathrm{~m}$ wide and $25 \mathrm{~m}$ long, received either one (WC1) or two years (WC2) of weed control treatment. First growing season weed control (October 1994) was a banded application of $7 \mathrm{~L} \mathrm{ha}^{-1}$ of hexazinone applied to all treatment plots using a manual-pumping device. In addition, radiata pine natural regeneration was removed by hand. Second growing season weed control (November 1995) was a manual cutting of roble ( $N$. obliqua) sprouts growing on the site prepared beds. 
One year after establishment (December 1995), a reference single plot adjacent to each block was incorporated into the trial. Seedlings within the supplemental plots were planted in July 1994 (a week after initial established seedlings) with a mix of the top five genetic ranking halfsib families, which were of similar genetic material and family ranking, and plants were produced in the same nursery as the seedlings in the other plots. The plots had the same dimensions and site preparation as the rest of the study, but pre-planting weed control. Seedlings were fertilized with $2.5 \mathrm{~g}$ of boron after planting. This treatment was considered a low intensity treatment (LIT) and was compared as a reference to the intensive treatments described above. Practical differences in genetic material, time of planting, and planting procedures that may have caused negative or positive effects on tree growth of the LIT plots were considered negligible.

Growth. Root collar diameter at $5 \mathrm{~cm}$ height $(\mathrm{RCD})$ and total height (HT) were measured at $0,2,6,14$ and 31 months after fertilization. Crown diameter (CR) was measured only at 31 months after fertilization. All measurements were taken on the inner $15 \mathrm{~m}$ square plots corresponding to 24 to 33 measured trees per plot.

Climate. Annual rainfall records were obtained from a rainfall gauging station located less than $10 \mathrm{~km}$ from the trial. Annual rainfall during 1994 and 1995 was 837 and $759 \mathrm{~mm}$, respectively. Average climatic pattern for this site suggests a large period of water deficit during summer months (figure 1) (Santibáñez and Uribe 1993).

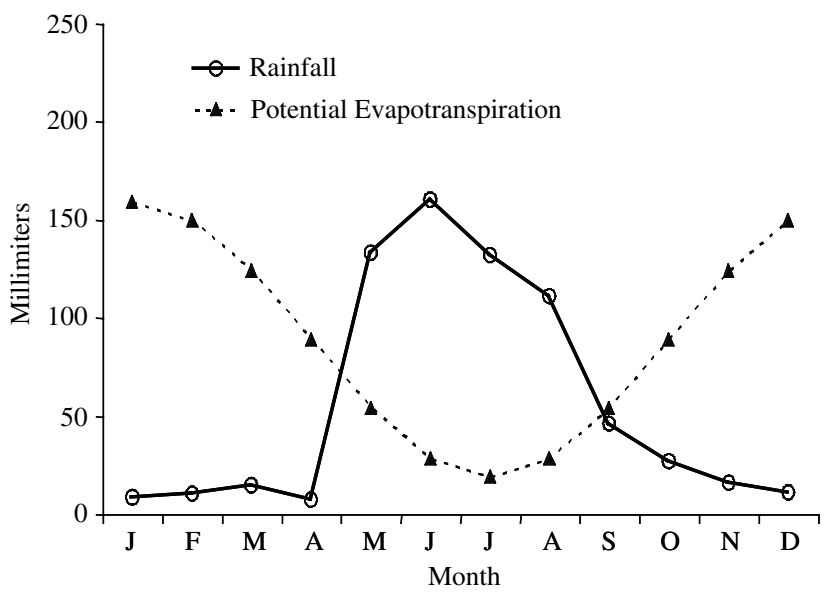

Figure 1. Pattern of annual rainfall $(\mathrm{mm})$ fluctuation for the duration of the study. Average climatic pattern of monthly rainfall $(\mathrm{mm})$ for the study location based on a local weather station (Forestal Celco S.A.). Potential evapotranspiration estimates were obtained using a Priestley-Taylor model (1972).

Patrón promedio de fluctuaciones de precipitación y evapotranspiración mensual $(\mathrm{mm})$ para la localidad del estudio. Valores de evapotranspiración potencial fueron estimados usando el modelo propuesto por Priestley-Taylor (1972).
Data analyses. Nine-month survival analyses were performed using ANOVA analyses using an arccosine transformation. Outliers were removed based on normal probability plots for each variable. Volume index $\left(\mathrm{V}=\mathrm{D}^{2} \mathrm{H}\right)$ was used as a surrogate for tree volume. A logarithmic transformation of this variable was applied to correct for heterocedasticity.

Analyses of variance (ANOVA) at the time of fertilization, showed no differences between fertilized and non-fertilized plots. In addition, regression analyses were used to evaluate covariates for initial measurements of the trial. These analyses indicated no need for covariates or pre-fertilization effects given the homogeneity of the starting material.

Analyses of variance at 2, 6, 14, and 31 months after fertilization were performed on growth variables. Due to the nature of the sequential application of the treatments, analyses were performed using two models. A randomized complete block design was used to analyze treatment effects on growth for all measurements, including the LIT treatment at 14 and 31 months (Model 1). At 31 months, the LIT treatment was excluded, and a split-plot model was used to analyze fertilization and weed control interactions (Model 2):

Model 1: $y_{i j}=\mu+\beta_{i}+\rho_{j}+(\beta \rho)_{i j}+\varepsilon_{i j}$

Model 2: $y_{i j k}=\mu+\beta_{i}+\rho_{j}+\omega_{k}+(\beta \rho)_{i j}+(\rho \omega)_{i k}+\varepsilon_{i j k .}$ [2]

Where $y_{i j k}$ response variable, $\mu$ overall mean, $\beta_{i}$ is the random effect associated with the $i^{\text {th }}$ block, $\rho_{j}$ is the fixed parameter associated with the $\mathrm{j}^{\text {th }}$ main plot fertilization treatment effect, $\omega_{k}$ is the fixed parameter associated with the $\mathrm{k}^{\text {th }}$ weed control duration sub-plot treatment effect, $\rho \omega_{i k}$ is the interaction between fertilization and weed control, $(\beta \rho)_{i j}$ is the whole plot random error associated with the ith block $\mathrm{x} \mathrm{j}^{\text {th }}$ fertilization treatment, and $\varepsilon_{i j k}$ is the random error. Analyses of residuals were used to evaluate bias and homogeneity of variance assumptions of the data and model fit. Multiple comparison tests were performed using a Tukey-Kramer test.

Linear regressions between volume index and crown diameter were compared among treatments using analysis of covariance (ANCOVA) including blocks and whole plots effects in the models. Treatment specific individual regression equations were tested using regression analysis with indicator variables for each site and treatment combination (Model 3):

Model 3: $\mathrm{LOG}_{10}\left(\mathrm{~V}_{\mathrm{ij}}\right)=\mathrm{a}+\mathrm{b} * \mathrm{Z}_{\mathrm{i}}+\mathrm{c} * \mathrm{LOG}_{10}\left(\mathrm{CR}_{\mathrm{ij}}\right)+$ $\mathrm{d} * \mathrm{Z}_{\mathrm{i}} * \mathrm{LOG}_{10}\left(\mathrm{CR}_{\mathrm{ij}}\right)+\varepsilon_{i j}$

Where $\mathrm{V}_{\mathrm{ij}}$ is the individual tree volume in $\mathrm{cm}^{3}, \mathrm{CR}_{\mathrm{ij}}$ is the crown diameter in $\mathrm{cm}, \mathrm{Z}_{\mathrm{i}}$ is the indicator variable for treatment effects (LIT, F0+WC1, F0+WC2, F1+WC1, F1+WC2), a, b, c, d are the coefficients of the model, $\varepsilon_{i j}$ is the random error, $i=1$ to 5 treatment effects, $j=1, \ldots, n_{i}$ trees in the ith treatment. For each equation, if interaction 
coefficients $b$ or $d$, were not significant, the terms were dropped from the models and reduced models were tested for intercept differences between regressions for each component (Model 4):

Model 4: $\mathrm{LOG}_{10}\left(\mathrm{~V}_{\mathrm{ij}}\right)=\mathrm{a}+\mathrm{b} * \mathrm{Z}_{\mathrm{i}}+\mathrm{c} * \mathrm{LOG}_{10}\left(\mathrm{CR}_{\mathrm{ij}}\right)+\varepsilon_{i j}[4]$

All the analyses were performed using SAS PROC MIXED and PROC GLM (SAS Institute v.9.1) and alpha errors of $5 \%$ and $10 \%$.

Lack of initial randomization of the LIT plots could have affected our results. However, LIT plots locations were established adjacent to each block and the selected areas were representative of the block soil conditions.

Foliage. Foliage was sampled by block one month prior to fertilization, and by treatment 31 months after fertilization. Composite foliar samples were obtained from 20 randomly selected trees. Foliage was collected from the upper third of the crown until $200 \mathrm{~g}$ of sample was obtained (Will 1985). Foliar samples were analyzed for nitrogen using a Kjeldahl digestion procedure. Phosphorus was determined using a colorimetric determination after development of the phosphomolibdate complex. Calcium, $\mathrm{K}, \mathrm{Mg}, \mathrm{S}, \mathrm{Zn}, \mathrm{Mn}$, $\mathrm{Fe}$, and $\mathrm{Cu}$, were determined using an atomic absorption spectrophotometer.

\section{RESULTS}

First year survival and cumulative growth. Fourteen months after establishment, fertilization did not increase survival
$(P=0.139)$. However, greater survival $(P=0.003)$ was observed on weed control plots with or without fertilization (96\% to $100 \%$ ) compared with LIT plots (83\%).

Cumulative growth showed significant differences among treatments at each evaluation of the trial (table 1, figures $2 \mathrm{~A}$ and 2B). Two months after fertilization, ANOVA analyses indicated a significant positive response to fertilization $(P<$ 0.01). Average percent gains of $23 \%$ in RCD, $19 \%$ in HT, and $70 \%$ in $\mathrm{V}$ were observed for fertilized seedlings. The initial responses and gains to fertilization were maintained for 6 months after treatment application (table 1).

Fourteen months after fertilization, no significant differences in HT, RCD or V were observed for the initial fertilization treatments (table 1). Low intensity treatment plots (LIT), with only boron fertilization and no weed control, were also evaluated at this time. Cumulative RCD, HT and $\mathrm{V}$ showed large and significant $(P<0.05)$ responses to weed control and complete fertilization $(\mathrm{N}+\mathrm{K}+\mathrm{B})$ (table 1 , figure 2). An average $62 \%$ gain in $\mathrm{RCD}, 33 \%$ in $\mathrm{HT}$, and $251 \%$ in $\mathrm{V}$, was obtained for the treatments, including one year of weed control compared to LIT at 14 months since fertilization. Tree size on LIT plots at 14 months was similar to the size of trees at 6 months on plots that had received weed control.

Third year growth responses. After 31 months, there were significant differences $(P<0.01)$ among treatments for all measured growth variables (table 1). Statistical contrasts showed significant differences between LIT and all other treatments. At 31 months there were no significant differences between fertilized and unfertilized plots (table 1, figures $2 \mathrm{~A}$ and $2 \mathrm{~B}$ ). The major response was predominately

Table 1. Least squares means, standard errors, statistical significance difference and multiple comparisons of treatment plot means for individual tree RCD, HT, and V at 0, 2, 6 months, and at 14 months and 31 months after fertilization including LIT treatment (Model 1). All differences among means were significant at a $P$-value $<0.01$.

Medias, errores estándar, diferencia estadística significativa y comparaciones múltiples de las medias de tratamientos para RCD, HT, y V a los 0, 2 y 6 meses, y a los 14 y 31 meses después de la fertilización, incluyendo el tratamiento LIT (Modelo 1). Todas las diferencias entre las medias fueron significativas a un valor de probabilidad de $P<0,01$.

\begin{tabular}{|c|c|c|c|c|c|c|c|c|c|c|c|c|c|c|c|c|}
\hline \multirow[b]{2}{*}{ Treatment } & \multicolumn{3}{|c|}{0 months } & \multicolumn{3}{|c|}{2 months } & \multicolumn{3}{|c|}{6 months } & \multicolumn{3}{|c|}{14 months } & \multicolumn{4}{|c|}{31 months } \\
\hline & $\begin{array}{l}\text { RCD } \\
(\mathrm{cm})\end{array}$ & $\begin{array}{l}\mathrm{HT} \\
(\mathrm{cm})\end{array}$ & $\begin{array}{c}\mathrm{V} \\
\left(\mathrm{cm}^{3}\right)\end{array}$ & $\begin{array}{l}\mathrm{RCD} \\
(\mathrm{cm})\end{array}$ & $\begin{array}{l}\mathrm{HT} \\
(\mathrm{cm})\end{array}$ & $\begin{array}{c}\mathrm{V} \\
\left(\mathrm{cm}^{3}\right)\end{array}$ & $\begin{array}{l}\mathrm{RCD} \\
(\mathrm{cm})\end{array}$ & $\begin{array}{l}\text { HT } \\
(\mathrm{cm})\end{array}$ & $\begin{array}{c}\mathrm{V} \\
\left(\mathrm{cm}^{3}\right)\end{array}$ & $\begin{array}{l}\mathrm{RCD} \\
(\mathrm{cm})\end{array}$ & $\begin{array}{l}\text { HT } \\
(\mathrm{cm})\end{array}$ & $\begin{array}{c}\mathrm{V} \\
\left(\mathrm{cm}^{3}\right)\end{array}$ & $\begin{array}{l}\text { RCD } \\
(\mathrm{cm})\end{array}$ & $\begin{array}{l}\mathrm{HT} \\
(\mathrm{cm})\end{array}$ & $\begin{array}{c}\mathrm{V} \\
\left(\mathrm{cm}^{3}\right)\end{array}$ & $\begin{array}{l}\text { CR } \\
(\mathrm{cm})\end{array}$ \\
\hline $\mathrm{F} 0+\mathrm{WC} 1$ & $0.49 \mathrm{a}$ & $33 a$ & $7.3 \mathrm{a}$ & $0.65 a$ & $40 \mathrm{a}$ & $16.6 \mathrm{a}$ & $1.00 \mathrm{a}$ & $55 \mathrm{a}$ & $51.6 \mathrm{a}$ & $2.12 \mathrm{a}$ & $97 \mathrm{a}$ & $402 \mathrm{a}$ & $6.2 \mathrm{a}$ & $239 a$ & $8037 a$ & $108 \mathrm{a}$ \\
\hline $\mathrm{F} 1+\mathrm{WC} 1$ & $0.47 \mathrm{a}$ & $31 b$ & $6.6 \mathrm{a}$ & $0.78 b$ & $46 b$ & $26.6 b$ & $1.26 \mathrm{~b}$ & $61 b$ & $89.2 b$ & $2.55 \mathrm{a}$ & $108 \mathrm{a}$ & $596 a$ & $6.5 \mathrm{a}$ & $254 \mathrm{a}$ & $9395 a$ & $114 \mathrm{a}$ \\
\hline $\mathrm{F} 0+\mathrm{WC} 2$ & na & na & na & na & na & na & na & na & na & na & na & na & $5.7 \mathrm{a}$ & $216 a$ & $6108 \mathrm{a}$ & $99 a$ \\
\hline $\mathrm{F} 1+\mathrm{WC} 2$ & na & na & na & na & na & na & na & na & na & na & na & na & $5.1 \mathrm{a}$ & $212 \mathrm{a}$ & $4504 a$ & $85 \mathrm{ab}$ \\
\hline LIT & na & na & na & na & na & na & na & na & na & $1.44 \mathrm{~b}$ & $77 b$ & $142 b$ & $3.2 \mathrm{~b}$ & $139 b$ & $1200 b$ & $63 b$ \\
\hline Std. Error & 0.01 & 0.20 & $0.02 *$ & 0.01 & 0.20 & $0.01 *$ & 0.05 & 0.80 & $0.04 *$ & 0.19 & 7 & $0.12 *$ & 0.52 & 25 & $0.14 *$ & 10 \\
\hline$P$-value & 0.420 & 0.051 & 0.249 & 0.026 & 0.003 & 0.011 & 0.079 & 0.037 & 0.071 & 0.02 & 0.01 & 0.03 & $<0.01$ & $<0.01$ & $<0.01$ & $<0.01$ \\
\hline
\end{tabular}

RCD: Root collar diameter. HT: Total height. V: Volume as RCD ${ }^{2 * H T}$. CR: crown diameter F0: No fertilization. F1: $26 \mathrm{~g}+16.7 \mathrm{~g}$ K+2.5g B per plant. WC1: one year of weed control. WC2: two years of weed control. na: not available. * Standard error in logarithmic form.

RCD: Diámetro de cuello, HT: Altura, V: Volumen como RCD ${ }^{2}$ HT. CR: diámetro de copa F0: Sin fertilización, F1: 26g N+16,7g K+2,5g B por planta, WC1: Un año de control de malezas, WC2: Dos años de control de malezas. na: no disponible. * Error estándar en forma logarítmica. 

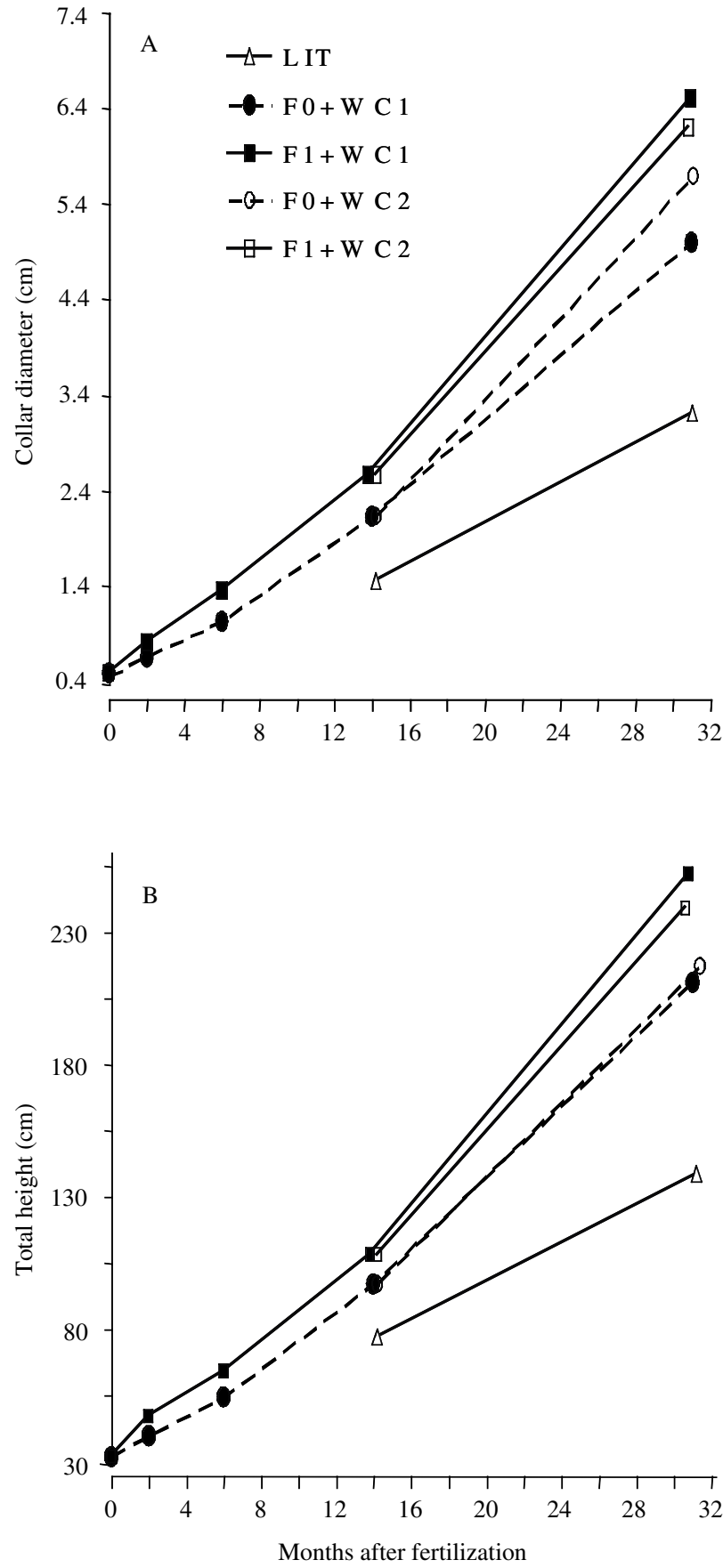

Figure 2. Tree growth versus time by treatment since establishment for A) collar diameter and B) height. LIT: Operational control after 14 months since fertilization, F0+WC1: No fertilization +1 year of weed control, F0+WC2: No fertilization +2 years of weed control, F1+WC1: Fertilization at establishment +1 year weed control, F1+WC2: Fertilization at establishment +2 years weed control.

Crecimiento del árbol en el tiempo por tratamiento desde el establecimiento para A) diámetro de cuello y B) altura. LIT: control operacional instalado después de 14 meses desde la fertilización. F0+WC1: sin fertilización +1 año de control de malezas. F0+WC2: sin fertilización +2 años de control de malezas. F1+WC1: fertilización al establecimiento +1 año de control de malezas. F1+WC2: fertilización al establecimiento +2 años de control de malezas. an effect of weed control over the LIT treatment. Analyses of variance using Model 2, excluding LIT and comparing the factorial nature of the initial treatments applied $(\mathrm{F} 0+\mathrm{WC} 1, \mathrm{~F} 0+\mathrm{WC} 2, \mathrm{~F} 1+\mathrm{WC} 1$ and $\mathrm{F} 1+\mathrm{WC} 2)$, showed no main effects of fertilization, weed control duration, or significant interactions between weed control and fertilization for cumulative growth (table 2).

Although not statistically significant, there was a trend of increased RCD and V growth on fertilized plots (figures 2A and 3). Gains in cumulative growth after 31 months for the best response treatment $(\mathrm{F} 1+\mathrm{WC} 1)$ compared to LIT were $103 \%$ in RCD, $81 \%$ in HT, $682 \%$ in $\mathrm{V}$, and $81 \%$ in $\mathrm{CR}$ (table 2).

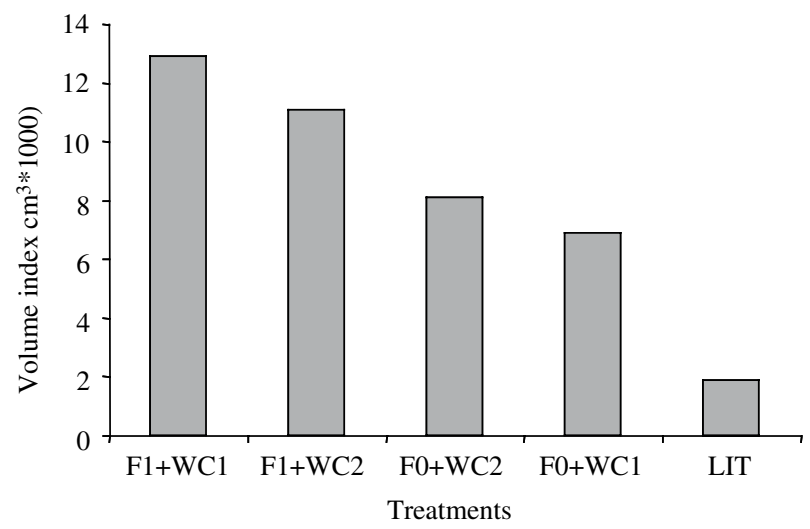

Figure 3. Average tree volume index (collar diameter ${ }^{2} \mathrm{x}$ height) at 31 months since establishment.

Índice de volumen promedio por árbol $\left(\mathrm{RCD}^{2 *} \mathrm{H}\right)$ a los 31 meses después de la aplicación del fertilizante.

Table 2. Statistical significance $(P$-value $>F)$ indicating fertilization, weed control, and interaction effects on root collar diameter (RCD), total height (HT), crown diameter (CR) and volume (V) at 31 months after fertilization, excluding the LIT treatment (Model 2).

Significancia estadística $(P$-value $>\mathrm{F})$ para los efectos de la fertilización, control de malezas, y la interacción de ambos tratamientos en el diámetro de cuello (RCD), altura total (HT), diámetro de copa $(\mathrm{CR})$ y volumen $(\mathrm{V})$ a los 31 meses después de la fertilización, excluye el tratamiento LIT (Modelo 2).

\begin{tabular}{lccccc}
\hline Source & df & RCD & HT & CR & V \\
\hline Fert & 1 & $0.2905^{\text {ns }}$ & $0.1986^{\text {ns }}$ & $0.2648^{\text {ns }}$ & $0.3169^{\text {ns }}$ \\
WC & 1 & $0.5831^{\text {ns }}$ & $0.5538^{\text {ns }}$ & $0.5556^{\text {ns }}$ & $0.6203^{\text {ns }}$ \\
Fert*WC & 1 & $0.1907^{\text {ns }}$ & $0.3347^{\text {ns }}$ & $0.1498^{\text {ns }}$ & $0.1723^{\text {ns }}$ \\
\hline
\end{tabular}

Fert: fertilization. WC: weed control. df: degrees of freedom. ns $=$ not significant $(P>0.05)$.

$\mathrm{ns}=$ no significativo

Individual tree volume and crown diameter. A significant linear relationship for $\mathrm{V}$ and $\mathrm{CR}\left(P<0.001, \mathrm{R}^{2}=0.99\right)$ was obtained after logarithmic transformation of both 
variables (figure 4). The general regression model (Model 4), using a zero "b" coefficient, had an "a" intercept coefficient of $-1.696(P<0.001)$, and a slope coefficient of $2.772(P<0.001)$.

Testing the homogeneity of this equation, there were significant differences $(P<0.01)$ in the intercept of the regression lines for LIT and all other treatments (table 4, figure 4$)$. In addition, significant differences $(P<0.01)$ in slope were observed among the LIT, WC1 and WC2 and treatments (table 3, figure 4).

Table 3. Tree individual volume (V) vs. crown diameter (CR) regression equations comparison between contrasting treatments. Treatment (TRT) effects on slope (Model 3) and intercepts (Model 4).

Comparación de líneas de regresión entre volumen de árbol individual (V) y diámetro de copa (CR) para los distintos tratamientos. Efecto de los tratamientos (TRT) en la pendiente (Modelo 3) y los interceptos correspondientes (Modelo 4).

\begin{tabular}{lcc}
\hline Treatments compared & $\begin{array}{c}\text { Full model } \\
\text { Different slopes } \\
P \text {-value }\end{array}$ & $\begin{array}{c}\text { Reduced model } \\
\text { Different intercepts } \\
P \text {-value }\end{array}$ \\
\hline LIT vs. F0+WC1 & $0.022^{*}$ & $<0.001^{* *}$ \\
LIT vs. F0+WC2 & $0.976^{\mathrm{ns}}$ & $<0.001^{* *}$ \\
LIT vs. F1+WC1 & $0.058^{*}$ & $<0.001^{* *}$ \\
LIT vs. F1+WC2 & $0.219^{\mathrm{ns}}$ & $<0.001^{* *}$ \\
F0+WC1 vs. F0+WC2 & $0.048^{*}$ & $0.773^{\mathrm{ns}}$ \\
F0+WC1 vs. F1+WC1 & $0.640^{\mathrm{ns}}$ & $0.837^{\mathrm{ns}}$ \\
F0+WC1 vs. F1+WC2 & $0.001^{* *}$ & $0.979^{\mathrm{ns}}$ \\
F0+WC2 vs. F1+WC1 & $0.114^{\mathrm{ns}}$ & $0.938^{\mathrm{ns}}$ \\
F0+WC2 vs. F1+WC2 & $0.311^{\mathrm{ns}}$ & $0.777^{\mathrm{ns}}$ \\
F1+WC1 vs. F1+WC2 & $0.002^{* *}$ & $0.841^{\mathrm{ns}}$ \\
\hline
\end{tabular}

Models tested:

Model 3, full model: $\mathrm{LOG}_{10}(\mathrm{~V})=\mathrm{a}+\mathrm{b} * \mathrm{TRT}+\mathrm{c} * \mathrm{LOG}_{10}(\mathrm{CR})+\mathrm{d} *(\mathrm{TRT} *$ $\mathrm{LOG}_{10}(\mathrm{CR})$ ).

Model 4, reduced model: $\mathrm{LOG}_{10}(\mathrm{~V})=\mathrm{a}+\mathrm{b} * \mathrm{TRT}+\mathrm{c} * \mathrm{LOG}_{10}(\mathrm{CR})$.

$\mathrm{V}$ in $\mathrm{cm}^{3}, \mathrm{CR}$ in $\mathrm{cm}$, TRT= dummy variable with 0 or 1 values for each treatment respectively.

LIT: low intensity treatment. F0: no fertilization. F1: $26 \mathrm{~g} \mathrm{~N}+16.7 \mathrm{~g}$ $\mathrm{K}+2.5 \mathrm{~g}$ B per plant. WC1: One year of weed control. WC2: Two years of weed control.

$* P<0.05 ; * * P<0.01 ; * * * P<0.001 ;$ ns $=$ not significant.

Modelos evaluados:

Modelo 3, Modelo completo: $\mathrm{LOG}_{10}(\mathrm{~V})=\mathrm{a}+\mathrm{b} * \mathrm{TRT}+\mathrm{c} * \mathrm{LOG}_{10}(\mathrm{CR})$ $+\mathrm{d}^{*}\left(\mathrm{TRT} * \mathrm{LOG}_{10}(\mathrm{CR})\right)$,

Modelo 4, Modelo reducido: $\mathrm{LOG}_{10}(\mathrm{~V})=\mathrm{a}+\mathrm{b} * \mathrm{TRT}+\mathrm{c} * \mathrm{LOG}_{10}(\mathrm{CR})$.

$\mathrm{V}$ en $\mathrm{cm}^{3}, \mathrm{CR}$ en $\mathrm{cm}, \mathrm{TRT}=$ variable con valores 0 y 1 para cada tratamiento.

LIT: Tratamiento de baja intensidad silvícola, F0: Sin fertilización, F1: $26 \mathrm{~g} \mathrm{~N}+16.7 \mathrm{~g} \mathrm{~K}+2.5 \mathrm{~g}$ B por planta, WC1: un año de control de malezas, WC2: dos años de control de malezas.

$*=P<0,05 ; * *=P<0,01 ; * * *,=P<0,001 ;$ ns $=$ no significativo.

Nutritional assessments. Foliage nutritional assessment before fertilization showed low nutrient levels for nitrogen (1.2\%), cupper $\left(6 \mathrm{mg} \mathrm{kg}^{-1}\right)$ and boron $\left(10 \mathrm{mg} \mathrm{kg}^{-1}\right)$ (Will
1985). No significant differences were detected among blocks for foliar nutrient levels, indicating similar nutritional conditions before fertilization $(P=0.59)$. Three years after fertilization, foliar cupper levels were critical for all treatments ( 4 to $5 \mathrm{mg} \mathrm{kg}^{-1}$ ), nitrogen levels were moderate (1.47-1.65\%). Boron levels were above critical values for all treatments (Will 1985, 1990), but there were significant differences $(P<0.01)$ between fertilized $(25 \mathrm{mg}$ $\left.\mathrm{kg}^{-1}\right)$ and non-fertilized plots $\left(14 \mathrm{mg} \mathrm{kg}^{-1}\right)$ three years after fertilization. Other potential critical nutrients at this stage of plantation development, were well above critical levels phosphorus $(0.15 \%)$, potassium $\left(0.55 \mathrm{mg} \mathrm{kg}^{-1}\right)$, calcium $\left(0.25 \mathrm{mg} \mathrm{kg}^{-1}\right)$ and magnesium $\left(0.14 \mathrm{mg} \mathrm{kg}^{-1}\right)$ but have no differences among treatments (Will 1985, 1990).

\section{DISCUSSION}

First year survival. Increased survival of radiata pine due to weed control has been reported elsewhere (Cellier and Stephens 1980, Smethurst and Nambiar 1989). Weed control effects on survival have been related to improved water and nutrient availability, increased rooting volume, and the removal of allelopathic limitations interfering with root growth (Nambiar 1984a, Will 1985, Gerding et al. 1987, Kogan and Figueroa 1999). In this study, the increase in survival to weed control but not fertilization, suggests that water is the major limiting factor for young seedling survival at this site.

Seedling growth. Although there is contradictory information regarding the effects of fertilization at establishment of fast-growing conifers (Wollons and Snowdon 1981, Ballard 1984, Donald et al. 1987, Gerding et al. 1987), large cumulative growth responses to weed control and fertilization have been reported in radiata pine (Nambiar 1984b, Gerding et al. 1987, Mason and Milne 1999). Nutritional demands in young plantations are usually low compared to site nutrient availability after harvesting (Allen et al. 1990, Smethurst and Nambiar 1990), reducing early responses to fertilization (Smethurst and Nambiar 1990, Fife and Nambiar 1997, Allen et al. 2001). The transient initial response to fertilization, regardless of weed control, suggests a nutrient limitation at this site, particularly in the top soil horizons (Schlatter and Gerding 1984, Schlatter 1987, Louw 1991). It is likely that there was little or no water limitation during the first six months after fertilization so the response to fertilization was not limited by water availability. The wildfire that burned the previous stand may have caused nutrient losses through volatilization and erosion (Kimmins 1996).

At 14 months there were no differences between fertilized and unfertilized plots, but there was a large response to weed control. Several authors have indicated the importance of combining site preparation, weed control, and fertilization to maximize tree growth (Barker 1978, Prado 


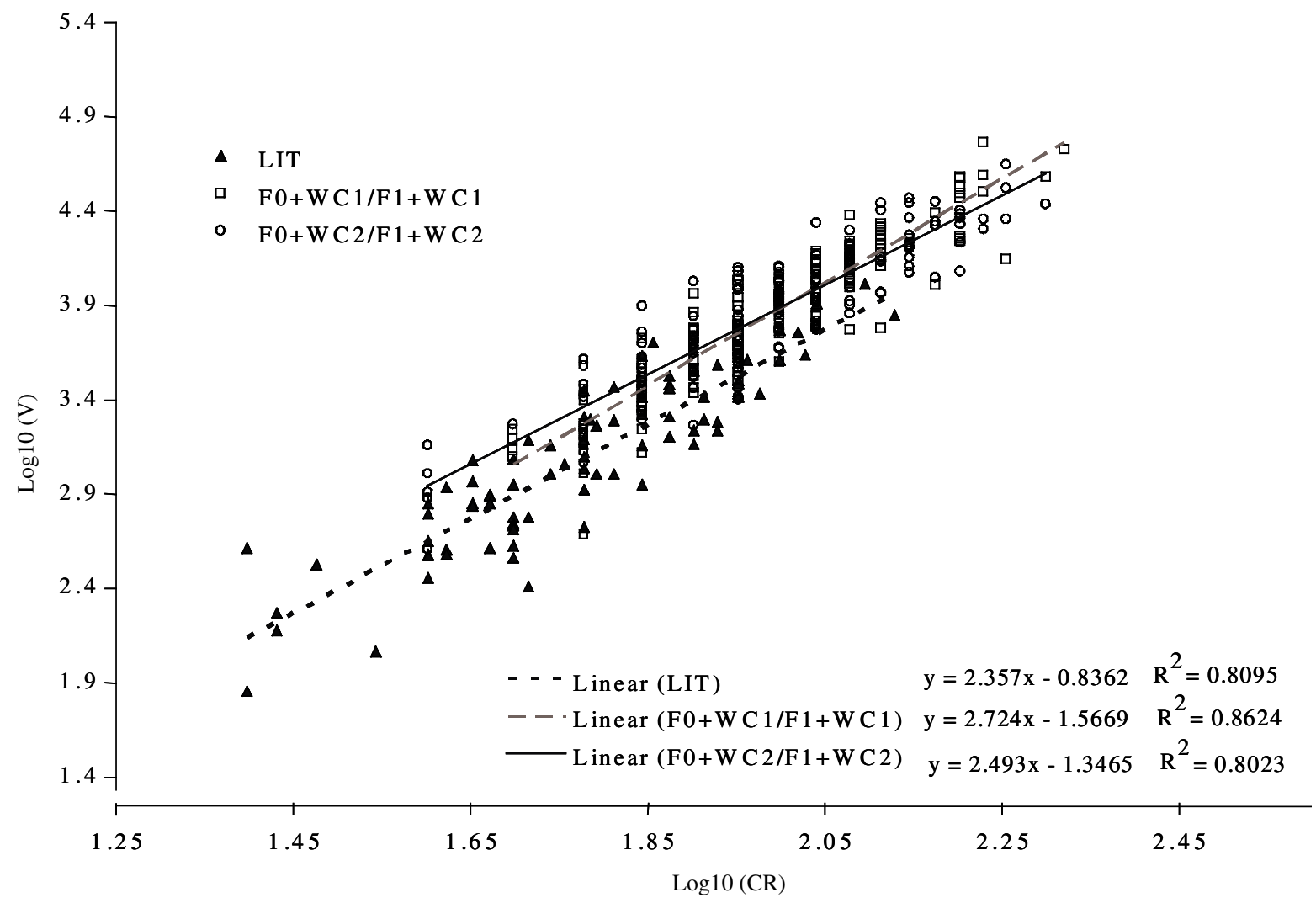

Figure 4. Individual tree regression equations comparison among treatments for crown diameter (CR) and volume index (V) at 31 months since establishment. LIT: Operational control, F0+WC1: No fertilized +1 year of weed control, F0+WC2: No fertilized +2 years of weed control, F1+WC1: Fertilized at establishment +1 year weed control, F1+WC2: Fertilized at establishment 2 years weed control.

Comparación de líneas de regresión a nivel de árbol individual entre tratamientos para diámetro de copa (CR) e índice de volumen (V) a los 31 meses después de la aplicación de fertilizante. LIT: control operacional. F0+WC1: sin fertilización +1 año de control de malezas. F0+WC2: sin fertilización + 2 años de control de malezas. F1+WC1: fertilización al establecimiento + 1 año de control de malezas. F1+WC2: fertilización al establecimiento +2 años de control de malezas.

and Wrann 1988). However, in all these works, weed control has been indicated as the most important silvicultural technique to enhance the growth of newly planted conifers. Large responses are usually observed after the first two growing seasons (Waring 1981, Balneaves 1982, Kogan et al. 1992). In our study, response relative to the LIT treatment increased from 14 to 31 months. The largest gains were obtained with only one year of weed control (WC1). Water stress is a major constraint to fertilization response (McMurtrie et al. 1990, Nambiar 1990) and often the major limitation for pine growth on dry sites (Watt et al. 2003a). The rainfall patterns for this area cause large water deficits during the growing season, which may have increased the response to weed control.

Resource demands increase exponentially as individual trees grow and crowns expand (Allen 1987, Nambiar 1990). Therefore, as stands develop, tree growth may decline if there are resource limitations (Nambiar and Bowen 1986, Schlatter 1987, Allen et al. 1990). The decline in the magnitude of response of the $\mathrm{F} 1+\mathrm{WC} 1$ treatment relative to the $\mathrm{F} 0+\mathrm{WC} 1$ treatment at 31 months suggests that resource limitations may have developed during the second growing season in the fertilized plots due to increased tree demand for resources or a return to pre-fertilization levels of nutrient availability. The positive but modest response in $\mathrm{RCD}, \mathrm{CR}$, and V to second year weed control for nonfertilized treatments, suggests that improvements in resource availability obtained in the first growing season have been maintained in the second growing season.

Three major patterns of stand and tree growth response to silvicultural treatments over time have been described (Snowdon and Waring 1984, Morris and Lowery 1988, Richardson et al. 1993, Snowdon 2002, Nilsson and Allen 2003, South et al. 2006). A sustained increase in growth until rotation age (type A or II), a transient response in growth but the initial gain is sustained through rotation (type B or I), and an initial response that decreases over time, vanishing at rotation age, and not changing significantly site resource availability (type C). Type A (Pritchett and Comerford 1982, Gent et al. 1986) responses have been 
related with fertilization of deficient sites, or improved aeration on poorly drained sites. Both silvicultural treatments cause a large shift in site resources and have long lasting effects. Type B responses have been observed with weed control on fertile sites (Mason and Milne 1999, Albaugh et al. 2004) due to an improvement in the timing of resource acquisition. Type $\mathrm{C}$ responses (Haywood and Tiarks 1990, Richardson 1993, Allen and Lein 1998) have been related to weed control on nutrient limited sites where only a short term effect on resource availability is made. The duration of response to weed control in radiata pine and other species has been reported (Creighton et al. 1987, Miller et al. 1991, Mason et al. 1999, Kogan et al. 2002, Watt et al. 2003ab). However, there is little information about responses when woody vegetation is controlled and when vegetation control is combined with fertilization. In addition to competing for nutrients and water, woody vegetation competes for light and, therefore, may have a long-term detrimental effect on pine growth (Richardson 1993). A more detailed analysis of biomass accumulations of competing vegetation would have increased our scope of the magnitude of weeds on site resource availability.

The importance of water availability during the first year suggests a type $\mathrm{B}$ or $\mathrm{C}$ response for weed control for these sites (Miller 1986, Allen et al. 1990). Our early assessment of tree growth response indicates a two-year sustained response to first growing season weed control and may account for a one year "age-shift" gain in stand development if a type B response is assumed (South et al. 2006). Unfortunately, no measurements were available from these trials at older ages to understand the current response of our treatments at this site.

Crown diameter and volume relationship. The allometric relationship between crown diameter (CR) and volume index (V) was explored in our study. Relationships between CR (a surrogate for leaf area) and $\mathrm{V}$ have not been reported comparing silvicultural treatments at establishment. Differences in intercepts for this relationship (higher cumulative $\mathrm{V}$ by unit of CR) were found between low and high intensity silviculture treatments, supporting a larger effect of water availability than nutrients on leaf area development (Raison et al. 1992) or efficiency (Fife and Nambiar 1997). Slope differences were found between the LIT and weed control treatments, suggesting an increase in foliar efficiency or specific leaf area for weed controlled and fertilized treatments (Linder et al. 1987, Raison et al. 1992, Fassnacht and Gower 1997). Differences in leaf area development and growth efficiency for specific treatment combinations have been reported for other fast growing species (Albaugh et al. 1998, Sampson and Allen 1999). Our results suggest that CR could be considered a surrogate for leaf area at early stages of development where senescence is low (Kirongo 2002) and may represent a simplified measure of tree vigor for use in assessing early plantation development.
Nutritional assessments. Foliar assessment at the beginning of the study indicated fairly homogeneous nutritional conditions among blocks and the need for fertilization (Hunter et al. 1990, Will 1990). High foliar nutrient levels may be required to maximize radiata pine growth (Crane and Banks 1992, Fife and Nambiar 1997). Lower foliar boron concentration on weed control plots compared to LIT plots and fertilized plots suggest a dilution of boron may have occurred. Boron availability for radiata pine has been linked to soil profile development and moisture availability (Ryan 1989, Lambert and Ryan 1990). The ephemeral initial response to fertilization at our site may be associated with the seasonal constraints on water availability. This may suggest a boron induced deficiency during the growing season that may be hampering tree growth. In addition, first year weed control effects are related with the transient but intensive effect of shallow rooting system of predominant competitors at this site (Nambiar 1983, 1984c). This may suggest that boron availability may be one of the most critical nutrients due to its high mobility that increases at deeper layers in the soil profile (Lambert and Ryan 1990).

\section{CONCLUSIONS}

Weed control of woody vegetation during the first growing season after establishment of radiata pine on metamorphic soils of the Coastal Range of Chile is crucial and provides gains in tree growth and stand development of one growing season. Second growing season weed control of woody vegetation provides no improvements on tree growth regardless of fertilization treatment. The large effects of weed control seem to be related to improvements in water availability at these sites. Fertilization effects at establishment had only a transient response, suggesting large water availability limitations on nutrient uptake. The linear relationship established between crown diameter, a surrogate for leaf area, and $\mathrm{V}$ suggests a simplified method to estimate tree vigor at early stages of plantation development. Weed control changed the relationship between crown diameter and growth, suggesting water availability may limit pine growth on these sites.

\section{ACKNOWLEDGEMENTS}

We would like to acknowledge the valuable initial review of this manuscript by Dr. Jamie Schuler (Hardwood Cooperative) from NC State University. We also acknowledge the enthusiastic field support of Mr. Pedro Burgos (BIOFOREST S.A.) and financial support from Forestal Celco S.A. We also would like to acknowledge the valuable comments of two anonymous reviewers. 


\section{REFERENCES}

Albaugh TJ, HL Allen, PM Dougherty, LW Kress, JS King. 1998. Leaf-area and above- and belowground growth responses of loblolly pine to nutrient and water additions. Forest Science 44: 317-328.

Albaugh TJ, R Rubilar, J Alvarez, HL Allen 2004. Radiata pine response to tillage fertilization and weed control in Chile. Bosque 25: 5-15.

Allen HL. 1987. Forest fertilizers. Journal of Forestry 85(2): 37-46.

Allen HL, PM Dougherty, RG Campbell. 1990. Manipulation of water and nutrients practice and opportunity in southern U.S. pine forests. Forest Ecology and Management 30: 437-453.

Allen HL, S Lein. 1998. Effects of site preparation, early fertilization, and weed control on 14-year old loblolly pine. In Proccedings of the Southern Weed Science Society N ${ }^{0} 51$, Birmingham, Ala., 26-29 January, USA. p. 104-110.

Allen HL, DL Kelting, TJ Albaugh. 2001. Nutrient management concepts and practices in southern pine plantations. In Bamsey $\mathrm{C}$ ed. Enhanced forest management: Fertilization and economics. Clear Lake Ltd. Edmonton, Canada. p. 27- 31.

Allen HL, TR Fox, RG Campbell. 2005. What is ahead for intensive pine plantation silviculture in the South? Southern Journal of Applied Forestry 29(2): 62-69.

Ballard R. 1984. Fertilization of plantations. New Zealand Journal of Forestry Science 8(1): 71-104.

Balneaves J. 1982. Grass control for radiata pine establishment on droughty sites. New Zealand Journal of Forestry 27(2): 259-276.

Balneaves JM, D Henley. 1992. Seven years growth response of radiata pine to area of herbaceous weed control. In Popey AJ ed. Proceedings of the $45^{\text {th }}$ New Zealand Plant Protection Conference, 13, August Wellington, New Zealand. p. 262-263.

Barker J. 1978. Silvicultural effects of fertilization. New Zealand Journal of Forestry Science 8(1): 161-177.

Cellier K, C Stephens. 1980. Effect of fertilizer and weed control on the early growth of Pinus radiata D. Don. in Southern Australia. Australian Forestry Research 10: 141-153.

CIREN (Centro de Información de Recursos Naturales, CL). 1999. Estudio Agrológico IX Región. Descripciones de Suelos, Materiales y Símbolos. Santiago Chile. 322 p.

Crane W, J Banks. 1992. Accumulation and retranslocation of nitrogen in fertilised and irrigated Pinus radiata. Forest Ecology and Management 52: 201-224.

Creighton J, B Zutter, G Glover, D Gjerstad. 1987. Planted pine growth and survival responses to herbaceous vegetation control, treatment duration, and herbicide application technique. Southern Journal of Applied Forestry 11: 223-228.

Donald D, P Lange, C Schutz, A Morris. 1987. The application of fertilizers to pines in Southern Africa. South African Forestry Journal 141: 53-62.

Fassnacht K, S Gower. 1997. Interrelationships among the edaphic and stand characteristics, leaf area index, and aboveground net primary production of upland forest ecosystems in north central Wisconsin. Canadian Journal of Forest Research 27(7): 1058-1067.

Fife D, EKS Nambiar. 1997. Changes in the canopy and growth of Pinus radiata in response to nitrogen supply. Forest Ecology and Management 93: 137-152.
Geldres E, J Schlatter. 2004. Crecimiento de las plantaciones de Eucalyptus globulus sobre suelos rojo arcillosos de la provincia de Osorno, Décima Región, Chile. Bosque 25(1): 95-101.

Gent JA, HL Allen, RG Campbell, CG Wells. 1986. Magnitude and duration, and economic analysis of loblolly pine growth response following bedding and phosphorus fertilization. Southern Journal of Applied Forestry 10: 124-128.

Gerding V. 1991. Manejo de las plantaciones de Pinus radiata D. Don en Chile. Bosque 12(2): 3-10.

Gerding V, J Schlatter, L Barriga. 1987. Fertilización para el establecimiento de Pinus radiata D. Don en Valdivia. Bosque 7(2): 127-128.

Haywood JD, AE Tiarks. 1990. Eleventh-year results of fertilization, herbaceous, and woody plant control in a loblolly pine plantation. Southern Journal of Applied Forestry 14: 173177.

Hunter I, G Will, M Skinner. 1990. A strategy for the correction of boron deficiency in radiata pine plantations in New Zealand. Forest Ecology and Management 37(1-3): 77-82.

INFOR (Instituto Forestal, CL). 2004. Estadísticas Forestales 2003. Boletín Estadístico $N^{\circ} 101$. Santiago, Chile.

INFOR (Instituto Forestal, CL). 2006. Estadísticas Forestales 2005. Boletín Estadístico Nº117. Santiago, Chile.

Kimmins J. 1996. Forest Ecology: A Foundation for Sustainable Forest Management. $2^{\text {nd }}$ edition. Upper Saddle River, NJ, USA. Prentice Hall. 596 p.

Kirongo BB, EG Mason, PA Nugroho. 2002. Interference mechanisms of pasture on the growth and fascicle dynamics of 3-year-old radiata pine clones. Forest Ecology and Management 159: 159-172.

Kogan M. 1992. Malezas, ecofisiología y estrategias de control. Colección en Agricultura. Santiago, Chile. Pontificia Universidad Católica de Chile. Facultad de Agronomía. $402 \mathrm{p}$.

Kogan M, R Fuentes, N Espinoza. 1992. Biología de malezas, herbicidas y estrategias de control en el sector forestal. Concepción, Chile. Fundación Chile, Pontificia Universidad Católica de Chile. 195 p.

Kogan M, R Figueroa. 1999. Interferencia producida por las malezas durante los dos primeros años en Pinus radiata. Bosque 20(1): 57-64.

Kogan M, R Figueroa, H Gilabert. 2002. Weed control intensity efects on young radiata pine growth. Crop Protection 21: 253-257.

Lambert M, P Ryan. 1990. Boron nutrition of Pinus radiata in relation to soil development and management. Forest Ecology and Management 30: 45-53.

Linder S, ML Benson, BJ Meyers, RJ Raison. 1987. Canopy dynamics and growth of Pinus radiata, I. Effects of irrigation and fertilization during a drought. Canadian Journal of Forest Research 17(10): 1157-1165.

Louw J. 1991. The relationship between site characteristics and Pinus radiata growth on the Tsitsikamma plateau. South African Journal of Forestry 158: 37-45.

Mason EG. 1994. Decision tools for establishing forest plantations. In Decision-Support 2001 conference, Toronto, Canada, September 12-16.

Mason EG, PG Milne. 1999. Effects of weed control, fertilisation and soil cultivation on the growth of Pinus radiata D.Don at mid-rotation in Canterbury. Canadian Journal of Forest Research 29: 985-982. 
McMurtrie R, M Benson, S Linder, S Running, T Talsma, W Crane, B Myers. 1990. Water/nutrient interactions affecting the productivity of stands of Pinus radiata. Forest Ecology and Management 30: 415-423.

Mead D. 2005. Opportunities for improving plantation productivity. How much? How quickly? How realistic? Biomass and Bioenergy 28: 249-269.

Miller H. 1986. Carbon x nutrient interactions-the limitations to productivity. Tree Physiology 2: 373-385.

Miller JH, BK Zutter, SM Zedaker, MG Edwards, JO Haywood, RA Newbold. 1991. A regional study on the influence of woody and herbaceous competition on early loblolly pine growth. Southern Journal of Applied Forestry 15: 169-179.

Morris LA, RF Lowery. 1988. Influences of site preparation on soil conditions affecting stand establishment and tree growth. Southern Journal of Applied Forestry 12: 170-178.

Nambiar EKS. 1983. Root development and configuration in intensively managed radiata pine plantations. Plant and Soil 71: 37-47

Nambiar EKS. 1984a. Plantation forest: their scope and perspective in plantation nutrition. In Bowen GD, EKS Nambiar eds. Chap. 1. Nutrition of plantation forest. London. UK. Academic Press. p. 1-16.

Nambiar EKS. 1984b. Manipulation of water and nutrients in plantations of fast growing species. In Grey DC, APG Schonau, CJ Schutz eds. Site and Productivity of Fast Growing Plantations. Proceedings IUFRO Symp. Forestry Research Institute. Department of Enviroment Affairs. Pretoria, South Africa. 30 April-11 May 1984. p. $489-506$.

Nambiar EKS. 1984c. Significance of first-order lateral roots on the growth of young radiata pine under environmental stress. Australian Forestry Research 14: 187-199.

Nambiar EKS, G Bowen. 1986. Uptake, distribution and retranslocation of nitrogen by Pinus radiata by $\mathrm{N}^{15}$-labelled fertilizer applied to podzolized sandy soil. Forest Ecology and Management 15: 269-284.

Nambiar EKS. 1990. Interplay between nutrients, water, root growth and productivity in young plantations. Forest Ecology and Management 30: 213-232.

Nambiar EKS, R Sands. 1993. Competition for water and nutrients in forests. Canadian Journal of Forest Research 23: $1995-1968$.

Nilsson U, HL Allen. 2003. Short- and long-term effects of site preparation, fertilization and vegetation control on growth and stand development of planted loblolly pine. Forest Ecology and Management 175: 367-377.

Powers RF, PE Reynolds. 1999. Ten year response of ponderosa pine plantations to repeated vegetation and nutrient control along an environmental gradient. Canadian Journal of Forest Research 29: 1027-1038.

Prado J, J Wrann. 1988. La importancia de la preparación del sitio y la fertilización en el establecimiento de plantaciones de Eucalyptus. In Actas Simposio Manejo Silvícola del Género Eucalyptus. Viña del Mar. Chile. p. 266-285.

Priestley CHB, RJ Taylor. 1972. On the assessment of surface heat flux and evaporation using large-scale parameters. Monthly Weather Review 100: 81-92.

Pritchett WL, NB Comerford. 1982. Long-term response to phosphorous fertilization on selected Coastal Plain soils. Soil Science Society of America Journal 46: 640-644.
Radosevich S, K Ousteryoung. 1987. Principles governing plant-environment interactions. In Walstad J, P Kuch eds. Chapter 5. Forest Vegetation Management for Conifer Production. Wiley Interscience Publication. Wiley and Sons. p. 105-156.

Raison RJ, BJ Myers, ML Benson. 1992. Dynamics of Pinus radiata foliage in relation to water and nitrogen stress: $\mathrm{I}$. Needle production and properties. Forest Ecology and Management 52: 139-58.

Richardson B. 1993. Vegetation management practices in plantation forest of Australia and New Zealand. Canadian Journal of Forest Research. 23: 1989-2005.

Richardson B, A Vanner, N Davenhill, J Balneaves, K Miller, J Ray. 1993. Interespecific competition between Pinus radiata and some common weed species, first-year results. New Zealand Journal of Forestry Science 23(2): 179-193.

Richardson B, MO Kimberly, JW Ray, GW Coker. 1999. Indices of interespecific plant competition for Pinus radiata in the central north island of New Zealand. Canadian Journal of Forest Research 29: 898-905.

Richardson B, M Watt, E Mason, D Kriticos. 2006. Advances in modelling and decision support systems for vegetation management in young forest plantations. Forestry 79(1): 29-42

Ryan P. 1989. Boron retention within a catena of rhyolitic soils and its effect on radiata pine growth and nutrition. Australian Journal of Soil Research 27(1): 135-148.

Sampson DA, HL Allen. 1999. Regional influences of soil available water and climate, and leaf area index on simulated loblolly pine productivity. Forest Ecology and Management 124: 1-12.

Santibáñez F, J Uribe. 1993. Atlas agroclimático de Chile, Regiones VI, VII y VIII. Laboratorio de Climatología. Departamento Ingeniería y Suelos. Universidad de Chile. Santiago, Chile. Ministerio de Agricultura, Fondo de Investigación Agropecuaria, CORFO. 99 p.

Schlatter J. 1987. La fertilidad del suelo y el desarrollo de Pinus radiata D. Don. Bosque 8(1): 13-19.

Schlatter J, V Gerding. 1984. Important site factors for Pinus radiata growth in Chile. In Grey DC, APG Schonau, CJ Schutz eds. Site and Productivity of Fast Growing Plantations. Proceedings IUFRO Symp. Forestry Research Institute, Department of Environment Affairs. Pretoria, South Africa. 30 April-11 May 1984. p. 957.

Smethurst PJ, EKS Nambiar. 1989. Role of weeds in the management of nitrogen in a young Pinus radiata plantation. New Forest 3: 203-224.

Smethurst PJ, EKS Nambiar. 1990. Effects of slash and litter management on fluxes of nitrogen and tree growth in a young Pinus radiata plantation. Canadian Journal of Forest Research 20: 1498-1507.

Snowdon P, H Waring. 1984. Long-term nature of growth responses obtained to fertilizer and weed control applied at planting and their consequences for forest management. In Grey DC, APG Schonau, CJ Schutz eds. Site and Productivity of Fast Growing Plantations. Proceedings IUFRO Symp. Forestry Research Institute, Department of Environment Affairs. Pretoria, South Africa. 30 April-11 May 1984. p. 701-711.

Snowdon P. 2002. Modeling Type 1 and Type 2 growth responses in plantations after application of fertilizer or other silvicultural treatments. Forest Ecology and Management 163(1-3): 229-244. 
South D, J Miller, M Kimberly, C Vanderschaaf. 2006. Determining productivity gains from herbaceous vegetation management with 'age-shift' calculations. Forestry 79(1): 43-56.

Toro J, R Rubilar, C González. 1998. Métodos para aumentar la productividad de plantaciones de Pinus radiata y Eucalyptus globulus entre las regiones VII y VIII, Chile. In Manejo Sustentable de los Recursos Forestales. Desafío del Siglo XXI. Primer Congreso Latinoamericano-IUFRO. Valdivia, Chile. 22 al 28 Noviembre.

Toro J. 2004. Alternativas silvícolas para aumentar la rentabilidad de las plantaciones forestales. Bosque 25(2): 101-113.

Turner J, M Lambert, P Hopmans, J McGrath. 2001. Site variation in Pinus radiata plantations and implications for site specific management. New Forests 21: 249-282.

Turner J, M Lambert, J Toro. 2003. Site classification for specific management of radiata pine plantations. In Gale MR, RF Powers, JR Boyle eds. Proceedings of the 10th North American Forest Soils Conference, Saulte. Ste. Marie, Ontario, Canada. July 2003.

Valdebenito G, M Hormazábal. 2000. Sistema de gestión forestal para la modernización de pequeños propietarios. Análisis de costos de establecimiento de plantaciones forestales en pequeñas propiedades atingente al Decreto Ley 701. INFOR. Proyecto FDI. Documento de Trabajo $\mathrm{N}^{\mathrm{o}} 120$, Chile.
Waring H. 1981. Forest fertilization in Australia: early and late. In Turvey ND ed. Proceedings Australian Forest Nutrition Workshop, Productivity in Perpetuity. Melbourne, Australia. CSIRO. 367 p.

Watt MS, D Whitehead, EG Mason, B Richardson, MO Kimberley 2003a. The influence of weed competition for light and water on growth and dry matter partitioning of young Pinus radiata, at a dryland site. Forest Ecology and Management 183 (1-3): 363-376.

Watt MS, D Whitehead, B Richardson, EG Mason, AC Leckie. 2003b. Modelling the influence of weed competition on the growth of young Pinus radiata at a dryland site. Forest Ecology and Management 178(3): 271-286.

Watt MS, MO Kimberley, B Richardson, D Whitehead, EG Mason. 2004. Testing a juvenile tree growth model sensitive to competition from weeds, using Pinus radiata at two contrasting sites in New Zealand. Canadian Journal of Forest Research 34(10): 1985-1992.

Will G. 1985. Nutrient deficiencies and fertilizer use in New Zealand exotic forest. FRI Bulletin N $\mathrm{N}^{\circ} 97.53 \mathrm{p}$.

Will G. 1990. Influence of trace element deficiencies on plantation forestry in New Zealand. Forest Ecology and Management 37: $1-6$

Wollons R, P Snowdon. 1981. Theory and practice of forest fertilization. In Turvey ND ed. Proceedings Australian Forest Nutrition Workshop, Productivity in Perpetuity. Melbourne, Australia. CSIRO. 367 p. 